\title{
Helminth fauna of Astyanax fasciatus Cuvier, 1819, in two distinct sites of the Taquari River, São Paulo State, Brazil
}

\author{
Acosta, AA. ${ }^{a *}$, Queiroz, J. ${ }^{b}$ Brandão, H. ${ }^{a}$ and Silva, RJ. ${ }^{a}$

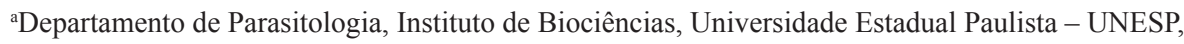 \\ Campus de Botucatu, Distrito de Rubião Júnior, s/n, CEP 18618-970, Botucatu, SP, Brazil \\ ${ }^{\text {b}}$ Departamento de Morfologia, Instituto de Biociências, Universidade Estadual Paulista - UNESP, \\ Campus de Botucatu, Distrito de Rubião Júnior, s/n, CEP 18618-970, Botucatu, SP, Brazil \\ *e-mail: alineacosta1@gmail.com
}

Received: August 13, 2013 - Accepted: October 4, 2013 - Distributed: March 31, 2015

(With 2 figures)

\begin{abstract}
This study assessed the helminth fauna of Astyanax fasciatus in two distinct sites of the Taquari River, São Paulo State, with 30 individuals sampled in a lotic site and 30 in a lentic site, recording the monogeneans: Cacatuocotyle paranaensis, Characithecium costaricensis, Diaphorocleidus kabatai, Jainus sp., Notozothecium sp. and Gyrodactylus sp., the digenean Antorchis lintoni and no-identified metacercariae; the nematode Procamallanus (Spirocamallanus) inopinatus and noidentified larvae. The mean abundances of total monogeneans $(U=1053 ; p=0.042)$ and C. costaricensis $(U=1107 ; p=$ $0.005)$ were higher in the lotic site. This difference may be due to the higher density of the host population in the lotic site, and the water transparence in lentic environments that prevents $A$. fasciatus to form shoals, precluding the exchange of parasites with direct cycle within a host population. This study is the first report of the helminth fauna of A. fasciatus in the Taquari River, with ten taxa recorded, and reports $A$. fasciatus as a new host for Notozothecium sp. and C. paranaensis.
\end{abstract}

Keywords: Neotropical fish, Astyanax fasciatus, parasites, Reservoir.

\section{Fauna de helmintos de Astyanax fasciatus Cuvier, 1819, em dois locais distintos do rio Taquari, estado de São Paulo, Brasil}

\begin{abstract}
Resumo
Este estudo avaliou a helmintofauna de Astyanax fasciatus em dois trechos distintos no rio Taquari, São Paulo, com 30 indivíduos coletados no trecho lótico e 30 no trecho lêntico, registrando os monogenóides: Cacatuocotyle paranaensis, Characithecium costaricensis, Diaphorocleidus kabatai, Jainus sp., Notozothecium sp. e Gyrodactylus sp., o digenético Antorchis lintoni e metacercárias não identificadas, o nematoide Procamallanus (Spirocamallanus) inopinatus e larvas não identificadas. A abundância média de monogenóides total $(U=1053 ; \mathrm{p}=0,042)$ e C. costaricensis $(\mathrm{U}=1107 ; \mathrm{p}=0,005)$ foi maior no trecho lótico. Esta diferença pode ser devido à densidade mais alta da população de hospedeiros no trecho lótico e à transparência da água em trechos lênticos que previne a formação de cardumes de $A$. fasciatus e a troca de parasitas com ciclo direto dentro da população de hospedeiros. Este estudo é o primeiro registro da helmintofauna de $A$. fasciatus no rio Taquari, com dez taxa encontrados, e registra $A$. fasciatus como novo hospedeiro para os monogenóides Notozothecium sp. e C. paranaensis.
\end{abstract}

Palavras-chaves: peixes Neotropicais; Astyanax fasciatus; parasitas; reservatório.

\section{Introduction}

The genus Astyanax Baird \& Girrard, 1854, include fishes known as "lambaris" or "piabas", and is one of the most rich and complex genus in terms of species within the family Characidae, occurring from the South of the United States to Argentina (Oyakawa, 2006). Astyanax spp. are relatively small (10 to $12 \mathrm{~cm}$ when adults), live in shoals, are restricted to freshwater, show morning habits, and good sights (Orsi, 2001). They are commercially appreciated, used for recreational fishing, and are potentially

useful for pisciculture (Andrade et al., 1985). They dwell the benthopelagic area of rivers, show annual and long reproductive period, partial spawning, and are also used as ornamental fish due to their colorful traits (Orsi, 2001).

Astyanax fasciatus is popularly known as "lambari do rabo vermelho", found along Upper Paraná River basin, and there is a higher frequency of capture of this fish in tributaries; the species shows light silver body color, red fins, cuspidate teeth, short reproductive dislocation, 
external fertilization, no parental care, and omnivorous feeding habit (Duke Energy, 2008). The helminth fauna of $A$. fasciatus has been studied for a long time, and the literature shows records of ten different species of monogeneans, 11 digeneans, and 13 nematodes (Table 1).
Several studies have been assessing fish parasite communities as indicators of environmental quality. VidalMartínez et al. (2010) summarized most of these studies from 1997 to 2008, and evaluated the changes in parasites communities related to eutrophication, pulp-mill effluents,

Table 1. List of helminth parasites species recorded in Astyanax fasciatus.

\begin{tabular}{|c|c|}
\hline Helminth species & Reference \\
\hline \multicolumn{2}{|l|}{ Monogenea } \\
\hline \multicolumn{2}{|l|}{ Gyrodactylidae } \\
\hline Gyrodactylus neotropicalis Kritsky and Fritts, 1970 & Kritsky and Fritts, 1970 \\
\hline Anacanthocotyle anacanthocotyle Kritsky and Fritts, 1970 & Kritsky and Fritts, 1970 \\
\hline \multicolumn{2}{|l|}{ Dactylogyridae } \\
\hline Characithecium costaricenses Price and Bussing, 1967 & Mendoza-Franco et al., 2009 \\
\hline Diaphorocleidus kabatai Molnar, Hanek, and Fernando, 1974 & Mendoza-Franco et al., 2009 \\
\hline Jainus hexops Kritsky and Leiby, 1972 & Kritsky and Leiby, 1972 \\
\hline Palombitrema heteroancistrium Price and Bussing, 1968 & Suriano, 1997 \\
\hline Urocleidoides astyanacis Gioia, Cordeiro, and Artigas, 1988 & Gioia et al., 1988 \\
\hline Urocleidoides costaricensis Price and Bussing, 1967 & Kritsky and Leiby, 1972 \\
\hline Urocleidoides heteroancistrium Price and Bussing, 1968 & Kritsky and Leiby, 1972 \\
\hline Urocleidoides strombicirrus Price and Bussing, 1967 & Price and Bussing, 1968 \\
\hline
\end{tabular}

Digenea

Antorchis lintoni Travassos, Artigas, and Pereira, 1928

Auriculostoma astyanace Scholz, Aguirre-Macedo, and Choudhury, 2004

Chalcinotrema ruedasueltensis Thatcher, 1978

Dadaytremoides grandistomis Thatcher, 1979

Genarchella parva Travassos, Artigas, and Pereira, 1928

Halipegus sp. Looss, 1899

Halipegus tropicus Manter, 1936

Prosorhynchus costai Travassos, Artigas and Pereira, 1928

Prosthenhystera obesa Diesing, 1850

Pseudoprosthenhystera microtesticulata Kloss, 1966

Saccocoelioides octavus Szidat, 1970

Travassos et al., 1928

Scholz et al., 2004

Kohn et al., 1999

Thatcher, 1979

Kohn et al., 1990

Kohn and Fernandes, 1987

Kloss, 1966

Travassos et al., 1928

Eiras et al., 2010

Kloss, 1966

Szidat, 1970

Nematoda

Capillaria sp. Zeder, 1800

Capillaria sentinosa Travassos, 1927

Capillostrongyloides sentinosa Travassos, 1927

Contracaecum sp. Larva Tipo 1 Moravec, Kohn, and Fernandes, 1993

Contracaecum sp. Larva Tipo 2 Moravec, Kohn, and Fernandes, 1993

Contracaecum sp. larva Railliet and Henry, 1912

Procamallanus (Spirocamallanus) hilarii Vaz and Pereira, 1934

Procamallanus (Spirocamallanus) iheringi Travassos, Artigas, and Pereira, 1928

Luque et al., 2011

Travassos et al., 1928

Travassos, 1927

Eiras et al., 2010

Eiras et al., 2010

Eiras et al., 2010

Eiras et al., 2010

Luque et al., 2011

Procamallanus (Spirocamallanus) inopinatus Travassos, Artigas, and Pereira, 1928

Procamallanus (Spirocamallanus) neocaballeroi Caballero-Deloya, 1977

Pinto and Noronha, 1976

Moravec and Vargas-

Vázquez, 1996

Procamallanus (Spirocamallanus) saofrancicensis Moreira, Oliveira and Costa, 1994

Luque et al., 2011

Rhabdochona acuminata Molin, 1860

Eiras et al., 2010

Rhabdochona fasciata Kloss, 1966

Kloss, 1966 
crude oil, PCBs (Polychlorinated Biphenyls), pesticides, and heavy-metals. However, there has not been any study in the literature comparing fish parasites communities in sites with distinct characteristics in a large reservoir.

The construction of hydroelectric power-plants, resulting in artificial reservoirs, is one of the most destructive activities in the Paraná river-basin, influencing the main river courses (Agostinho et al., 2008). The reservoirs have impacts on the fish assemblages, such as predominance of generalist species (Freeman et al., 2001), depletion of specialists and migratory species (Britto and Carvalho, 2006), and transference of pathogens and parasites (Gabrielli and Orsi, 2000). Since these impoundments affect the composition and abundance of fish assemblages, the prevalence and size of fish parasites infra-communities may also be affected (Pavanelli and Takemoto, 2000).

The Taquari River is the second biggest tributary formed by Jurumirim dam (Henry and Nogueira, 1999) and is one of the main tributaries of the Paranapanema River that suffers the impacts of the reservoir. There is a strong local interest in artisanal fishing in the Taquari River, due to the great diversity and abundance of fish. To date, there is no record of parasitological studies in this river. Thus, this study aimed to assess the helminth fauna of A. fasciatus in the Taquari River, São Paulo, and to compare for the first time the helminth communities of this host from different habitat types: lentic and lotic sites.

\section{Material and Methods}

\subsection{Study area}

Jurumirim dam is a hydric complex formed by a reservoir with $449 \mathrm{~km}^{2}$ of surface and three main tributaries: Paranapanema, Veados and Taquari rivers. Taquari River is in confluence with the left bank of the Upper Paranapanema River, located in the Southeast of São Paulo State $\left(23^{\circ} 15^{\prime} 11.9^{\prime \prime}\right.$; $\left.49^{\circ} 12^{\prime} 34.2^{\prime \prime} \mathrm{W}\right)$. The fluctuations of the water level are determined either by natural (rainy and dry seasons) or artificial events like the reservoir operation system (Luciano and Henry, 1998).

Astyanax fasciatus specimens were sampled in two sites: a lotic site located upstream in the main channel of the river $\left(23^{\circ} 40^{\prime} 2.90^{\prime \prime} \mathrm{S} ; 49^{\circ} 7^{\prime} 56.85^{\prime \prime} \mathrm{W}\right)$ with wide riparian forest, swamps and macrophytes; and a lentic site located in the river mouth, flooded by Jurumirim dam located approximately $10 \mathrm{~km}$ away from the impoundment $\left(23^{\circ} 17^{\prime} 2.80^{\prime \prime} \mathrm{S} ; 49^{\circ} 12^{\prime} 6.90^{\prime \prime} \mathrm{W}\right)$, with absence of riparian forest and macrophytes, banks occupied by pasture and agriculture, and sand extraction.

\subsection{Field and laboratory procedures}

The fish were sampled in November and December of 2011, using gill nets exposed by approximately 14 hours. The sample was composed of 60 fish: 30 specimens sampled in the lotic site and 30 in the lentic site, all specimens analyzed were adults. After sampling, the fish were individualized in plastic bags, frozen and taken to the laboratory to perform parasitological analyses. The standard length in centimeters $\left(\mathrm{L}_{\mathrm{s}}\right)$ and total weight in grams $\left(\mathrm{W}_{t}\right)$ of the specimens were measured.

Fish voucher specimens were deposited at the Museu de Zoologia da Universidade Estadual de Londrina (MZUEL 5669), Londrina, Paraná State, Brazil.

\subsection{Parasitological analyses}

The body, fins, nasal cavity, and the inner face of the operculum of the fish hosts were examined to find helminth ectoparasites. The gills were removed and washed using 53 and 75 micrometer sieves, placed in Petri plate and examined to find helminth parasites. Following the external analyses, a longitudinal incision in the ventral surface was made and all inner organs were removed and separated. The visceral cavity and all organs were examined using stereomicroscope to find helminth endoparasites. All collected helminthes were preserved in alcohol $70 \%$. For species identification, the monogeneans were cleared with Hoyer or Grey \& Wess to visualize the sclerotized structures, the digeneans were stained with carmine and cleared with creosote, and the nematodes were diaphonized with lactophenol (Eiras et al., 2006).

The parasites were identified based mainly on identification keys and reference guides and analyzed using the computerized system for image analysis Qwin Lite 3.1 (Leica). Representatives of the helminth species were deposited in the Coleção Helmintológica do Instituto de Biociências (CHIBB), UNESP, municipality of Botucatu, São Paulo State, Brazil.

\subsection{Statistical analysis}

The ecological terminology, prevalence, infection/ infestation mean intensity, and mean abundance were determined following Bush et al. (1997). The parasites were classified according to Bush and Holmes (1986) into core species (prevalence higher that $66.6 \%$ ), secondary species (prevalence between $33.3 \%$ and $66.6 \%$ ) and satellite species (prevalence less than $33 \%$ ).

To determine the ecological attributes of infracommunities the following diversity indexes were calculated: ShannonWinner: $\mathrm{H}^{\prime}=-\sum$ (pi.ln pi), used to measure the order or disorder in a system, attributing greater weight to rare species and relatively independent of sample size, in which: $\mathrm{H}^{\prime}=$ species diversity; $\mathrm{pi}$ = proportion of species $\mathrm{i}$ in the community, and $\mathrm{pi}=(\mathrm{ni} / \mathrm{N}): \mathrm{ni}=$ individuals number of $\mathrm{i}$ species and $\mathrm{N}=$ total number of individuals (Krebs, 1989; Begon et al., 2007); and the Berger-Parker index $(d=N \max / N)$ was used to measure the dominance of the species, in which Nmax = number of individuals of each abundance species, $\mathrm{N}=$ total number of individuals of all species (Krebs, 1989). The Shannon-Winner index was calculated and compared using the statistical program Past - Paleontological Statistics version $3.0(P<0.05)$.

Similarity analysis of parasite communities between the sites studied was carried out using Jaccard Coefficient that is based on the presence and absence of local species sampled, this index varies from 0 (dissimilar) to 1 (similar) and is calculated by the equation $(\mathrm{Q}=\mathrm{c} /(\mathrm{a}+\mathrm{b}-\mathrm{c}) .100)$, 
in which $\mathrm{Q}=$ Jaccard similarity coefficient; $\mathrm{c}=$ number of common species between $a$ and $b ; a=$ number of species sampled in $a ; b=$ number of species sampled in b (Krebs, 1989).

The index of discrepancy (D), described by Poulin (1993), was used to evaluate spatial distribution of parasites based on their abundance between lotic and lentic sites. This index varies from 0 to 1 , and can be interpreted as: $\mathrm{D}=0$, all hosts harboring the same number of parasites; $\mathrm{D}=1$, all parasites found in a single host. This analysis was calculated according to Rózsa et al. (2000) using the software Quantitative Parasitology 3.0.

The comparison among prevalence of parasites in the lotic and lentic sites was calculated with Z-test. The infection/infestation mean intensity and mean abundance between the two sites were calculated with Mann-Whitney $\mathrm{U}$ test. The statistical comparisons were made using the software SigmaStat 3.1. The statistical significance level adopted was $P<0.05$. A principal component analysis (PCA) was carried out to compare parasites communities in the lotic and lentic sites and this multivariate analysis was calculated with the software MVSP.

\section{Results}

\subsection{Parasites communities}

A richness of ten helminth taxa was found in the A. fasciatus samples analyzed in this study. For the lotic site, $93.3 \%$ of the hosts analyzed were parasitized by at least one helminth species (overall prevalence $=93.3 \%$ ). A total of 169 parasites were found, with six helminth parasite taxa, and a mean of 5.64 parasite/fish. The richness varied from 1 to 4 parasites and the mean richness was 2.3 parasites/fish (Table 2 ).

For the lentic site, $90 \%$ of the hosts analyzed were parasitized by at least one helminth species (overall prevalence $=90 \%$ ). A total of 169 parasites were found, with eight helminth parasite taxa, and a mean of 5.4 parasites/fish. The richness varied from 1 to 5 parasites and the mean richness was 2.3 parasites/fish (Table 2).

The monogeneans $C$. costaricensis and D. kabatai were the species with higher prevalence in the lotic and lentic sites, considered core species. Nematode larvae were secondary species and the other taxa were satellite species.

\subsection{Comparison between lotic and lentic sites}

The mean abundance of total monogeneans $(\mathrm{U}=1053$; $\mathrm{p}=0.042)$ and $C$. costaricensis $(\mathrm{U}=1107 ; \mathrm{p}=0.005)$ were greater in the lotic site (see Figure 1). The mean richness was similar between both sites, however the richness was greater in the lentic stretch. The overall prevalence $(z=-0.00467 ; p=0.996)$ and the total numbers of helminth found $(U=991 ; p=0,264)$ were similar between lotic and lentic sites.

The Jaccard index $(\mathrm{SJ}=0.7)$ demonstrated similarity between the parasite communities of both sites. The Shannon-Wiener index $($ Lotic $=1.15$; Lentic $=1.55$; $\mathrm{p}<0.001)$ demonstrated that in the lentic site the helminth communities show a diversity greater than in the lotic site. The Berger-Parker index demonstrated that $D$. kabatai was the dominant species in both sites. However C. costaricensis and nematode larvae demonstrated dominance indexes similar to $D$. kabatai in the lotic and lentic sites, respectively (Table 3). Most of the parasites species found in both sites showed aggregated distribution pattern. Only the species C. paranaensis, D. kabatai and no-identified nematode larvae showed median aggregation index (Table 3 ).

The multivariate analysis based on the component community of the helminth parasites of A. fasciatus allowed observing that there is not separation among the host specimens from lotic and lentic sites. Antorchis lintoni, nematode larvae, D. kabatai and C. costaricensis showed more importance in the analysis (see Figure 2).

\section{Discussion}

Most of the parasites found in this study corroborate previous records, however, there has not been any record of Notozothecium sp. and C. paranaensis in this host species, thus this study is the first record of these monogeneans in A. fasciatus. All the records represent a new geographic distribution for these parasites, since to date parasitological studies have not been conducted in the Taquari River, São Paulo State.

Berger-Parker index demonstrated that $D$. kabatai was the dominant species in both sites and $C$. costaricensis showed dominance index similar to D. kabatai. These monogeneans were first described parasitizing the gills of Astyanax spp. (Mendoza-Franco et al., 2009), and there is only one report of $D$. kabatai parasitizing A. altiparanae Garutti and Britsky, 2000 (Almeida and Cohen, 2011). Thus, this study corroborates the literature and strongly suggests the specificity of these monogeneans with the genus Astyanax.

Paraguassu and Luque (2007) studied the helminth fauna of $A$. fasciatus and observed a predominance of endoparasites, with the nematode Rhabdochona acuminata Molin, 1860, as the main component. However, they did not record monogeneans and digeneans. Kloss (1966) analyzed the occurrence of helminth parasites in simpatric species of Astyanax, including A. fasciatus, and found species of adult digeneans and nematodes. Moreover, species of Procamallanus (Procamallanus) Baylis, 1923 have often been recorded in Astyanax spp. (Table 1). Therefore, this study does not correlate with previous reports, since monogeneans were the dominant taxa showing the highest prevalence, infection intensity and abundance. Nonetheless, the records of the digenean $A$. antorchis and the nematode $P$. (Spirocamallanus) inopinatus in this study corroborate Travassos et al. (1928) and Pinto and Noronha (1976) respectively.

Dogiel (1961) states that monogenean are more frequently found in lentic environments, since it is easier for the free-swimming larval stages find the hosts, which does not correlate with this study, considering that a greater abundance of monogeneans was found in the lotic site. 


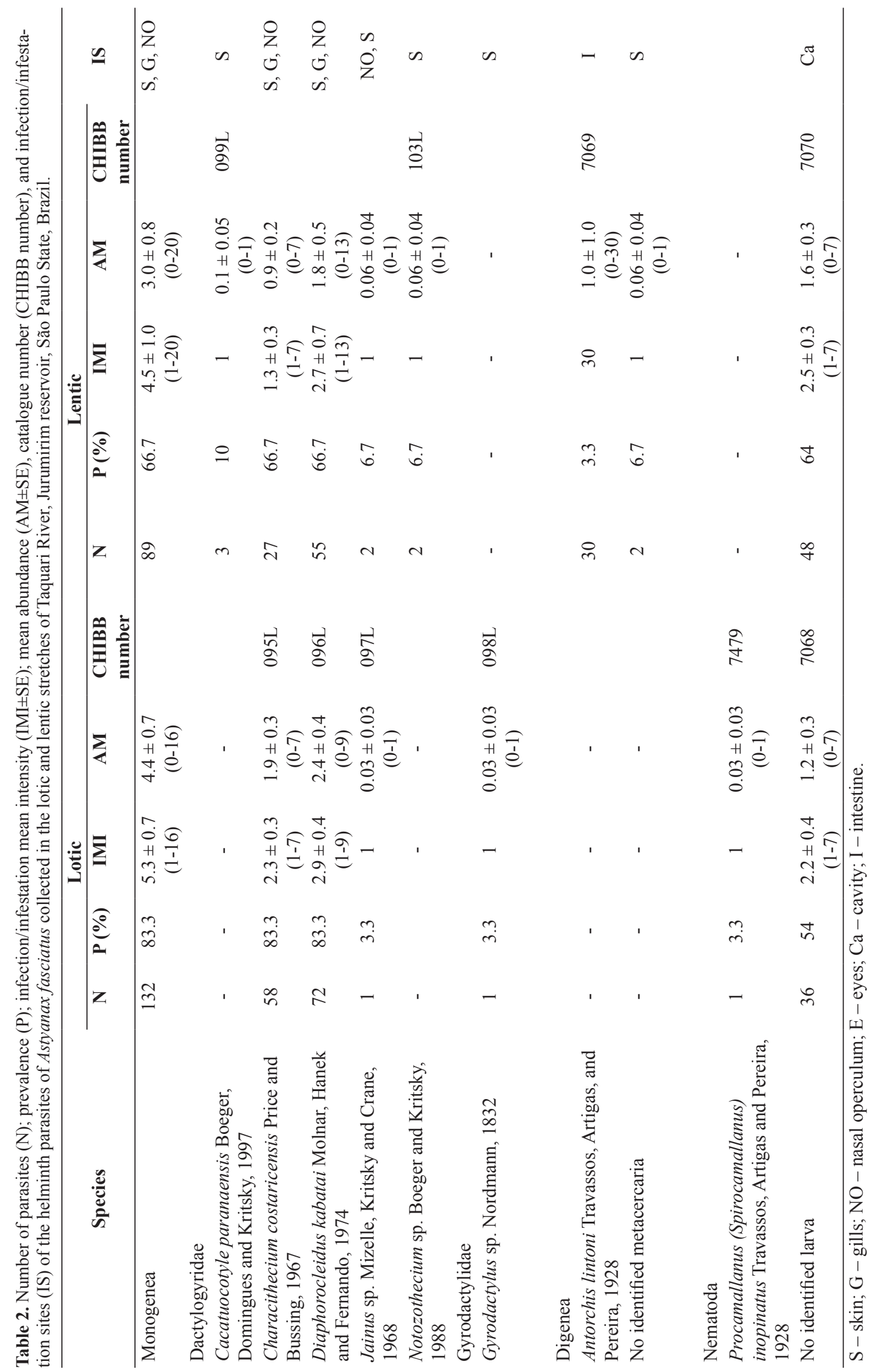




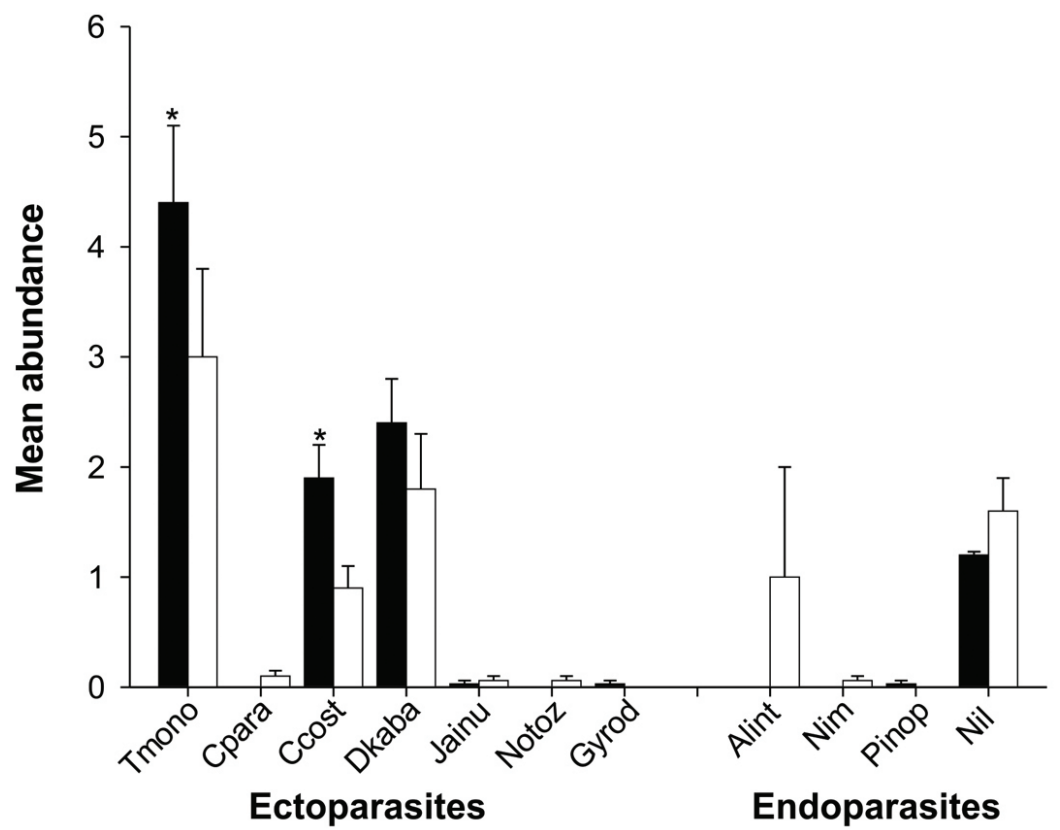

Figure 1. Mean abundance of helminths parasites of Astyanax fasciatus sampled in the lotic and lentic stretches of the Taquari River, Jurumirim reservoir, São Paulo State, Brazil. Caption: tMono - total monogenean; Cpara - Characithecium costaricensis; Dkaba - Diaphorocleidus kabatai; Jainu - Jainus sp.; Notoz - Notozothecium sp.; Girod - Gyrodactylus sp.; Alint - Antorchis lintoni; Nim - no identified metacercariae; Pinop - Procamallanus (Spirocamallanus) inopinatus; Nil - no identified larvae. ${ }^{*} \mathrm{p}<0.05$. Black bars: lotic stretch; White bars: lentic stretch.

Table 3. Berger-Parker and Aggregation indexes for the helminth species of Astyanax fasciatus sampled in the lotic and lentic stretches of Taquari River, Jurumirim reservoir, São Paulo State, Brazil.

\begin{tabular}{|c|c|c|c|c|}
\hline \multirow[b]{2}{*}{ Helminth } & \multicolumn{2}{|c|}{ Berger-Parker index } & \multicolumn{2}{|c|}{ Aggregation index } \\
\hline & Lotic & Lentic & Lotic & Lentic \\
\hline \multicolumn{5}{|l|}{ Monogenea } \\
\hline Cacatuocotyle paranensis & - & 0.018 & 0.469 & 0.646 \\
\hline Characithecium costaricensis & 0.343 & 0.16 & - & 0.871 \\
\hline Diapharocleidus kabatai & 0.426 & 0.325 & 0.462 & 0.607 \\
\hline Jainus sp. & 0.006 & 0.012 & 0.935 & 0.903 \\
\hline Notozothecium sp. & - & 0.012 & - & 0.935 \\
\hline Gyrodactylus sp. & 0.006 & - & 0.935 & - \\
\hline \multicolumn{5}{|l|}{ Digenea } \\
\hline Antorchis lintoni & & 0.178 & - & 0.935 \\
\hline No identified metacercaria & - & 0.012 & - & 0.935 \\
\hline \multicolumn{5}{|l|}{ Nematoda } \\
\hline Procamallanus (Spirocamallanus) inopinatus & 0.006 & - & 0.935 & - \\
\hline No identified larva & 0.213 & 0.284 & 0.645 & 0.542 \\
\hline
\end{tabular}

However, it must be considered that it is expected more chances of transmission of parasites with direct cycles in denser populations, due to the proximity of the individuals, as observed in farmed fishes (Franceschini et al., 2013) or in natural populations (Takemoto et al., 2005). The fish used in this study were sampled together with a fish ecology project that carried out eight sampling efforts in 2011 and 2012, and a greater amount of $A$. fasciatus was sampled in the lotic site during these two years (lotic $n=206$; lentic $\mathrm{n}=36$ ), suggesting that $A$. fasciatus population is denser in the lotic site.

Takemoto et al. (2005) studied the population density of different host species as the major determinant of endoparasite richness in floodplain fishes of the Upper Paraná River, Brazil. The authors elucidate that host species occurring at higher population density should harbor more species of parasites, and their result was a positive relationship between hosts density and parasites 


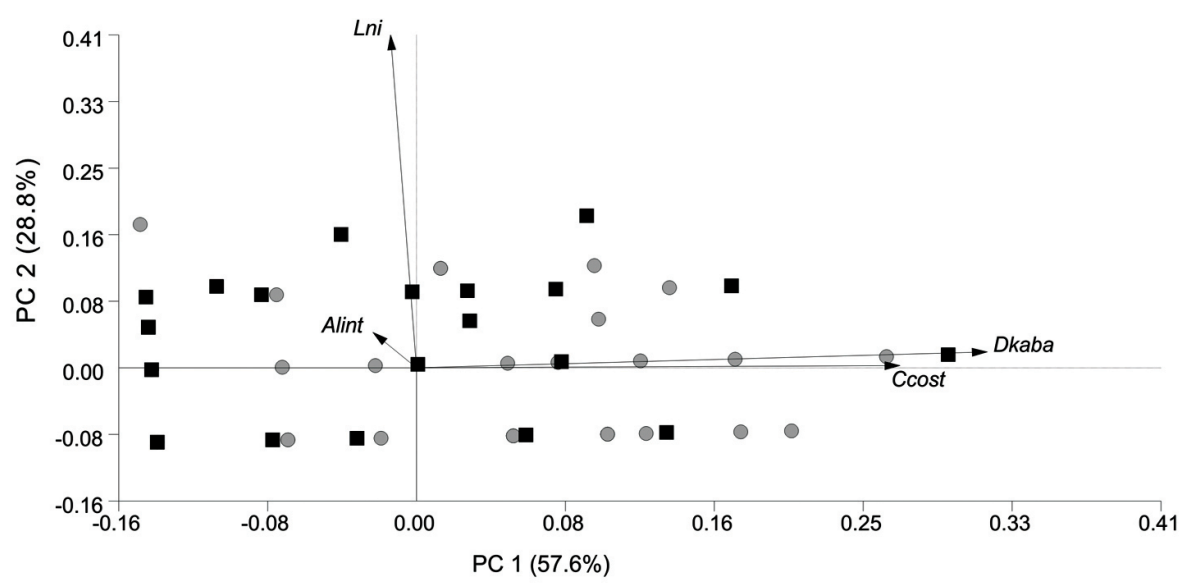

Figure 2. Scatterplot scores of the principal component analysis (PCA) of parasites communities of Astyanax fasciatus in the lotic stretch $(\circ)$ and lentic stretches $(\square)$ of the Taquari River, Jurumirim reservoir, São Paulo State, Brazil. The values showed in the ordinate and abscissa axes represent the greatest quantity and variation of the data set. Vectorial scale $=0.41$. Alint - Antorchis lintoni; Nil - no identified larvae; Dkab - Diaphorocleidus kabatai; Ccost - Characithecium costaricensis.

richness, a pattern in agreement with the epidemiological theory (Roberts et al., 2002), which predicts that the larger or denser the populations are, the more parasites populations they will support. Hence, the authors suggest that host density may develop the function of maintaining parasite species richness. Therefore, the greater abundance of the monogenean C. costaricensis in the lotic site might be associated with the greater amount of individuals in the population.

Additionally, it was observed that Astyanax spp. populations form schools and seek shelter in sites with abundance of macrophytes and organic matter in shoals close to the banks (Orsi et al., 2004). In these areas the effects of the water flow are attenuated (Champion and Tanner, 2000; Franklin et al. 2008), thus the currents might not be influencing the abundance of parasites in this host. The water transparence in lentic environments also prevents the populations of $A$. fasciatus of forming schools, which would make these fish more exposed to predators (Orsi et al., 2004; Tondato et al., 2010). Thus, the transmission of parasites with direct cycles from host to host would be hindered in lentic sites.

This study contributes with the first characterization of the helminthfauna of $A$. fasciatus in the Taquari River, with ten different taxa recorded, broadening the knowledge of geographic distribution for these parasites, and also reports $A$. fasciatus as a new host record for the monogenean Notozothecium sp. and C. paranaensis. Moreover, the greater abundance of $C$. costaricensis in the lotic site may be due to the higher density of the host population, and also due to the water transparence in lentic environments that prevents A. fasciatus to form shoals, precluding the exchange of parasites with direct cycle within a host population.

\section{Acknowledgements}

The authors thank FAPESP (2010/19543-6) and CAPES (AUX-PE-PNPD 3005/2010) for funding the project, CAPES for the scholarship granted to the first author; and Professor Edmir Daniel Carvalho who co-advised this study but unfortunately he is no longer with us to share the results of this research.

\section{References}

AGOSTINHO, AA., PELICICE, FM. and GOMES, LC., 2008. Dams and the fish fauna of the Neotropical region: impacts and management related to diversity and fisheries. Revista Brasileira de Biologia $=$ Brazilian Journal of Biology, vol. 68, supplement 4, p. 1119-1132. http://dx.doi.org/10.1590/S1519-69842008000500019. PMid:19197482

ALMEIDA, K S.S. and COHEN, S.C., 2011. Diversidade de Monogenea (Platyhelminthes) Parasitos de Astyanax altiparanae do Reservatório da Usina Hidrelétrica de Itaipu. Saúde \& Ambiente Revista, Duque de Caxias, vol. 6, no. 1, p. 31-41.

ANDRADE, DR., GODINHO, HP., RIBEIRO, SP. and CASTRO, EFT., 1985. Ciclo reprodutivo anual de lambaris Astyanax bimaculatus (Linnaeus, 1758) em viveiros. Arquivo Brasileiro de Medicina Veterinária e Zootecnia, vol. 37, no. 5, p. 435-347.

BEGON, M., TOWNSEND, CR. and HARPER, JL., 2007. Ecologia de indivíduos a ecossistemas. 4th ed. Artmed: Porto Alegre.

BRITTO, SGC. and CARVALHO, ED., 2006. Ecological attributes of fish fauna in the Taquaruçu Reservoir, Paranapanema River (Upper Parana, Brazil): composition and spatial distribution. Acta Limnologica Brasiliensia, vol. 18, no. 4, p. 377-388.

BUSH, AO. and HOLMES, JC., 1986. Intestinal helminthes of lesser scaup ducks: an interactive community. Canadian Journal of Zoology, vol. 64, no. 1, p. 142-152. http://dx.doi.org/10.1139/ z86-023. 
BUSH, AO., LAFFERTY, KD., LOTZ, JM. and SHOSTAK, AW., 1997. Parasitology meets ecology on its own terms: Margolis et al. revisited. The Journal of Parasitology, vol. 83, no. 4, p. 575-583. http://dx.doi.org/10.2307/3284227. PMid:9267395

CHAMPION, PD. and TANNER, CC., 2000. Seasonality of macrophytes and interaction with flow in a New Zealand lowland stream. Hydrobiologia, vol. 441, no. 1/3, p. 1-12. http://dx.doi. org/10.1023/A:1017517303221.

DOGIEL, VA., 1961. Ecology of the parasites of freshwater fishes. In DOGIEL, V.A., PETRUSHEVSKI, G.K. and POLYANSKI, YI. Parasitology of fishes. Leningrad: University Press. p. 1-47.

Duke Energy, 2008. Peixes do rio Paranapanema. 2nd ed. São Paulo: Horizonte Geográfico. 120 p.

EIRAS, JC., TAKEMOTO, RM. and PAVANELLI, GC., 2006. Métodos de estudo e técnicas laboratoriais em parasitologia de peixes. 2nd ed. Maringá: Eduem. 199 p.

EIRAS, JC., TAKEMOTO, RM. and PAVANELLI, GC., 2010. Diversidade de peixes de água doce do Brasil. Maringá: Clichetec. 333 p.

FRANCESCHINI, L., ZAGO, AC., SCHALCH, SHC., GARCIA, F., ROMERA, DM. and SILVA, RJ., 2013. Parasitic infections of Piaractus mesopotamicus and hybrid (P. mesopotamicus $\mathrm{x}$ Piaractus brachypomus) cultured in Brazil. Revista Brasileira de Parasitologia Veterinária, vol. 22, no. 3, p. 407-414. http:// dx.doi.org/10.1590/S1984-29612013000300015.

FRANKLIN, P., DUNBAR, M. and WHITEHEAD, P., 2008. Flow controls on lowland river macrophytes: a review. The Science of the Total Environment, vol. 400, no. 1-3, p. 369-378. http://dx.doi. org/10.1016/j.scitotenv.2008.06.018. PMid:18644618

FREEMAN, MC., BOWEN, ZH., BOVEE, KD. and IRWIN, ER., 2001. Flow and habitat effects on juvenile fish abundance in natural and altered flow regimes. Ecological Applications, vol. 11, no. 1, p. 179-190. http://dx.doi.org/10.1890/10510761(2001)011[0179:FAHEOJ]2.0.CO;2.

GABRIELLI, MA. and ORSI, ML., 2000. Dispersão de Lernea cyprinacea (Linnaeus) (Crustacea, Copepoda) na região norte do estado do Paraná, Brasil. Revista Brasileira de Zoologia, vol. 17, no. 2, p. 395-399. http://dx.doi.org/10.1590/S010181752000000200010 .

GIÓIA, I., CORDEIRO, NS. and ARTIGAS, PT., 1988. Urocleidoides astyanacis n. sp. (Monogenea: Ancyrocephalinae) from freshwater characidians of the genus Astyanax. Memorias do Instituto Oswaldo Cruz, vol. 83, no. 1, p. 13-15. http://dx.doi. org/10.1590/S0074-02761988000100002.

HENRY, R. and NOGUEIRA, MG., 1999. A Represa de Jurumirim (São Paulo): primeira síntese sobre o conhecimento limnológico e uma proposta preliminar de manejo ambiental. In HENRY, R. Ecologia de reservatórios: estrutura, função e aspectos sociais. Botucatu: Fapesp/Fundibio. p. 651-685.

KLOSS, GR., 1966. Helmintos parasitos de espécies simpátricas de Astyanax (Pisces: Characidae). Papéis Avulsos do Departamento de Zoologia de São Paulo, vol. 18, no. 17, p. 189-219.

KOHN, A. and FERNANDES, BMM., 1987. Estudo comparativo dos helmintos parasitos de peixes do rio Mogi guassu, coletados nas excursoes realizadas entre 1927 e 1985. Memorias do Instituto Oswaldo Cruz, vol. 82, no. 4, p. 483-500. http://dx.doi.org/10.1590/ S0074-02761987000400006. PMid:3507917
KOHN, A., FERNANDES, BMM., GIBSON, DI. and FRÓES, OM., 1990. On the Brazilian species of halipegine genera (Trematoda: Derogenidae) from fishes, with new morphological data, hosts and synonyms. Systematic Parasitology, vol. 16, p. 201-211. http://dx.doi.org/10.1007/BF00009148.

KOHN, A., FERNANDES, BM. and GIBSON, DI., 1999. Chalcinotrema thatcheri n. sp. (Digenea: Haploporidae) from Brazilian freshwater fishes, a redescription of $C$. ruedasueltensis Thatcher, 1978 and comments on the validity of the genus. Systematic Parasitology, vol. 44, no. 3, p. 211-215. http://dx.doi. org/10.1023/A:1006251722038. PMid:10629729

KREBS, CJ., 1989. Ecological methodology. New York: Harper \& Row.

KRITSKY, DC. and FRITTS, TH., 1970. Monogenetic trematodes from Costa Rica, with the proposal of Anacanthocotyle gen. $\mathrm{n}$. (Gyrodactylidae: Isancistrinae). Proceedings of the Helminthological Society of Washington, vol. 37, p. 63-68.

KRITSKY, DC. and LEIBY, PD., 1972. Dactylogyridae (Monogenea) from the freshwater fish, Astyanax fasciatus (CUVIER), in Costa Rica, with descriptions of Jainus hexops sp. n. Urocleidoides costaricensis and $U$. heteroancistrium combs. n. Proceedings of the Helminthological Society of Washington, vol. 39, p. 227-230.

LUCIANO, SC. and HENRY, R., 1998. Biomass of Eichhornia azurea Kunth. and Brachiaria arrecta Stent. in lower Taquari River, Jurumirim Reservoir, São Paulo, Brazil. Verhandlungen der Internationale Vereinigung für Theoretische und Angewandte Limnologie, vol. 26, p. 1857-1861.

LUQUE, JL., AGUIAR, JC., VIEIRA, FM., GIBSON, DI. and SANTOS, CP., 2011. Checklist of Nematoda associated with the fishes of Brazil. Zootaxa, vol. 3082, p. 1-88.

MENDOZA-FRANCO, EF., REINA, RG. and TORCHIN, ME., 2009. Dactylogyrids (Monogenoidea) parasitizing the gills of Astyanax spp. (Characidae) from Panama and southeast Mexico, a new species of Diaphorocleidus and a proposal for Characithecium N. Gen. The Journal of Parasitology, vol. 95, no. 1, p. 46-55. http://dx.doi.org/10.1645/GE-1592.1. PMid:19245277

MORAVEC, F. and VARGAS-VÁZQUEZ, J., 1996. The development of Procamallanus (Spirocamallanus) neocaballeroi (Nematoda: Camallanidae), a parasite of Astyanax fasciatus (Pisces) in Mexico. Folia Parasitologica, vol. 43, no. 1, p. 61-70. PMid:8682410.

ORSI, ML., 2001. Biologia populacional de Astyanax altiparanae Garutti e Britski, 2000, (Teleostei, Characidae) da bacia do rio Paranapanema (Baixo rio Tibagi). Botucatu: Universidade Estadual Paulista. 89 p. Dissertação de Mestrado.

ORSI, ML., CARVALHO, ED. and FORESTI, F., 2004. Biologia populacional de Astyanax altiparanae Garutti \& Britski, 2000 (Teleostei, Characidae) do médio rio Paranapanema, Paraná, Brasil. Revista Brasileira de Zoologia, vol. 21, no. 2, p. 207-218. http:// dx.doi.org/10.1590/S0101-81752004000200008.

OYAKAWA, OT., 2006. Peixes de riachos da Mata Atlântica nas Unidades de Conservação do Vale do Rio Ribeira de Iguape no Estado de São Paulo. São Paulo: Editora Neotrópica.

PARAGUASSÚ, AR. and LUQUE, JL., 2007. Metazoários parasitos de seis espécies de peixes do Reservatório de Lajes, Estado do Rio de Janeiro, Brasil. Revista Brasileira de Parasitologia Veterinária, vol. 16, no. 3, p. 121-128. http://dx.doi.org/10.1590/ S1984-29612007000300002. PMid:18078597

PAVANELLI, GC. and TAKEMOTO, RM., 2000. Aspects of the ecology of proteocephalid cestodes, parasites of Sorubim lima 
(Pimelodidae), of the upper Paraná River, Brazil: II. Interspecific associations and distribution of gastrintestinal parasites. Revista Brasileira de Biologia = Brazilian Journal of Biology, vol. 60, no. 4, p. 585-590. http://dx.doi.org/10.1590/S0034-71082000000400007. PMid:11241956

PINTO, RM. and NORONHA, D., 1976. Procamallanus brasileiros (Nematoda, Camallanoidea): considerações finais, com chave para determinação das espécies. Memorias do Instituto Oswaldo Cruz, vol. 74, no. 3-4, p. 323-339. http://dx.doi.org/10.1590/ S0074-02761976000300011.

POULIN, R., 1993. The disparity between observed and uniform distributions: a new look at parasite aggregation. International Journal for Parasitology, vol. 23, no. 7, p. 937-944. http://dx.doi. org/10.1016/0020-7519(93)90060-C. PMid:8106186

PRICE, CE. and BUSSING, WA., 1968. Monogenean parasites of Costa Rican fishes. Part II. Proposal of Palombitrema heteroancistrium n. gen., n. sp. Proceedings of the Helminthological Society of Washington, vol. 35, p. 54-57.

ROBERTS, MG., DOBSON, AP., ARNEBERG, P., DE LEO, GA., KRECEK, RC., MANFREDI, MT., LANFRANCHI, P. and ZAFFARONI, E., 2002. Parasite community ecology and biodiversity. In HUDSON, P.J., RIZZOLI, A., GRENFELL, B.T., HEESTERBEEK, H. and DOBSON, AP. The ecology of wildlife diseases. Oxford: Oxford University Press. p. 63-82.

RÓZSA, L., REICZIGEL, J. and MAJOROS, G., 2000. Quantifying parasites in samples of hosts. The Journal of Parasitology, vol. 86 , no. 2 , p. 228-232. http://dx.doi.org/10.1645/00223395(2000)086[0228:QPISOH]2.0.CO;2. PMid:10780537

SCHOLZ, T., AGUIRRE-MACEDO, ML. and CHOUDHURY, A., 2004. Auriculostoma astyanace n. gen., n. sp. (Digenea: Allocreadiidae), from the banded astyanax, Astyanax fasciatus (Characiformes: Characidae), from Nicaragua, with a reevaluation of neotropical Crepidostomum spp. The Journal of Parasitology, vol. 90, no. 5, p. 1128-1132. http://dx.doi.org/10.1645/GE-3275. PMid:15562614
SURIANO, DM., 1997. Palombitrema heteroancistrium Price \& Bussing, 1968 (Monogenea: Ancyrocephalidae) from Astyanax (A.) fasciatus fasciatus (Cuvier, 1819) (Pisces: Characidae) in Chascomús lake, argentina: anatomy and systematic position. Physis (Buenos Aires), vol. 53, p. 7-10.

SZIDAT, L., 1970. Saccocoelioides octavus n. sp., a new species of the genus Saccocoelioides Szidat, 1954 (Trematoda, Haploporinae Looss 1902). Revista del Museo Argentino de Ciencias Naturales. Bernardino Rivadavia Zoologia, vol. 10, no. 5 , p. $87-100$

TAKEMOTO, RM., PAVANELLI, GC., LIZAMA, MA., LUQUE, JL. and POULIN, R., 2005. Host population density as the major determinant of endoparasite species richness in floodplain fishes of the upper Paraná River, Brazil. Journal of Helminthology, vol. 79, no. 1, p. 75-84. http://dx.doi.org/10.1079/JOH2004264. PMid:15831117

THATCHER, V.E., 1979. Paramphistomidae (Trematoda: Digenea) de peixes de água doce: dois novos gêneros da Colômbia e uma redescricão de Dadaytrema oxycephala (DIESING, 1836) Travassos, 1934, da Amazônia. Acta Amazônica, vol. 9, p. 203-208.

TONDATO, KK., MATEUS, LAF. and ZIOBER, SR., 2010. Spatial and temporal distribution of fish larvae in marginal lagoons of Pantanal, Mato Grosso State, Brazil. Neotropical Ichthyology, vol. 8, no. 1, p. 123-134. http://dx.doi.org/10.1590/ S1679-62252010005000002.

TRAVASSOS, L., 1927. Uma nova Capillaria parasite de peixes de água doce. Capillaria sentinosa n. sp. Boletím de Biologia, vol. 10 , p. 215-217.

TRAVASSOS, L., ARTIGAS, P. and PEREIRA, C., 1928. Fauna helmintológica dos peixes de água doce do Brasil. Archivos do Instituto Biológico, vol. 1, p. 5-68.

VIDAL-MARTÍNEZ, VM., PECH, D., SURES, B., PURUCKER, T. and POULIN, R., 2010. Can parasites really reveal environmental impact? Trends in Parasitology, vol. 26, no. 1, p. 44-51. http:// dx.doi.org/10.1016/j.pt.2009.11.001. 